\title{
Juridische aspecten van zelfwerkzaamheid in huurwoningen
}

Citation for published version (APA):

Adriaansens, C. A. (1985). Juridische aspecten van zelfwerkzaamheid in huurwoningen. Kluwer. https://doi.org/10.26481/spe.19850920ca

Document status and date:

Published: 20/09/1985

DOI:

10.26481/spe.19850920ca

Document Version:

Publisher's PDF, also known as Version of record

\section{Please check the document version of this publication:}

- A submitted manuscript is the version of the article upon submission and before peer-review. There can be important differences between the submitted version and the official published version of record.

People interested in the research are advised to contact the author for the final version of the publication, or visit the DOI to the publisher's website.

- The final author version and the galley proof are versions of the publication after peer review.

- The final published version features the final layout of the paper including the volume, issue and page numbers.

Link to publication

\footnotetext{
General rights rights.

- You may freely distribute the URL identifying the publication in the public portal. please follow below link for the End User Agreement:

www.umlib.nl/taverne-license

Take down policy

If you believe that this document breaches copyright please contact us at:

repository@maastrichtuniversity.nl

providing details and we will investigate your claim.
}

Copyright and moral rights for the publications made accessible in the public portal are retained by the authors and/or other copyright owners and it is a condition of accessing publications that users recognise and abide by the legal requirements associated with these

- Users may download and print one copy of any publication from the public portal for the purpose of private study or research.

- You may not further distribute the material or use it for any profit-making activity or commercial gain

If the publication is distributed under the terms of Article $25 \mathrm{fa}$ of the Dutch Copyright Act, indicated by the "Taverne" license above, 


\title{
JURIDISCHE ASPECTEN \\ VAN ZELFWERKZAAMHEID \\ IN HUURWONINGEN
}

\author{
REDE
}

uitgesproken bij de anvaarding van het ambt van buitengewoon hoogleraar in het recht, in het bijzonder in het privaatrecht.

aan de Rijksuniversiteit Limburg te Maastricht op vrijdag 20 september 1985

door

MR. G.A. ADRIAANSENS 


\section{CIP-GEGEVENS KONINKLIJKE BIBLIOTHEEK, DEN HAAG}

Adriaansens, G.A.

Juridische aspecten van zelfwerkzaamheid in huurwoningen / door C.A. Adriaansens. - Deventer:

Kluwer

Inatugurele rede Maastricht.

ISBN $90-268-1575-1$

5150997.65 UDC $[365,27 ; 729.22] .000 .34$

Trefw: bewonerszelfbouw ; huurwoningen; juridische aspecten.

(6) $1985 \mathrm{Mr} \cdot \mathrm{C} . \mathrm{A}$. Adrianansens, Maasirucht

Behoudens uitzondering door de wet gesteld mag zonder schriftelijke toestermming vary de rechthebbende( $(\mathbf{n})$ op het auteursrecht, (c.q. de uitgever, door de rechthebbende( $\mathbf{n}$ ) gemachtigd namens hem (hen/haar) op te treden) niets uit deze uitgave worden verveelvoudigd en of openbaar gemaakt door middel van druk, fotocopie, microfilm of anderszins, hetgeen ook van toepassing is op de gehele of geded telijke bewerking.

De uitgefster (untgever) is met uitsluiting van ieder ander gerechtigd de in artikel 17, lid 2, Autcurswet $1912 \mathrm{en}$ in het KB van 20 juni 1974 (Stb. 351) bedoelde vergoeding te innen en/of daartoe in er buiten rechte op te treden. 


\section{INLEIDING}

De Nederlandler is, in vergelijking met de inwoners van andere westerse landen, nogal honkvast. Een huishouden woont in ons land gemiddeld 10 jaar lang op hetzelfde adres ${ }^{1}$. Aannemelijk is wel dat de verhuisfrequentie bij huurders, onder normale omstandigheden, iets hoger ligt dan bij eigen-woningbezitters - exacte c.q. bruikbare gegevens ontbreken op dit punt-maar ook een huurrelatie wordt ten onzent gemiddeld woor een reeks van jaren aangegaan ${ }^{2}$.

Het is begrijpelijk dat, waar de periode van bewoning van een huis zo lang is, ook in de huursector behoefte bestaat aan aanpassing van het gehuurde an de woonwensen en smaak van de huurder. Dat gebeurt dan ook op betekenende schaal: $70 \%$ van de Nederlanders boven de 12 jaar verricht wel cens karweitjes in en om de woning. De doe-het-zelf-branche vertoont cen flinke en gestage groei en de doe-het-zelver durft steeds grotere en moeilijker klussen aan ${ }^{4}$, daarbij geholpen door meer vrije tijd en/of gedwongen door stagnerend inkomen - en wie weet - de behoefte aan zelfverwerkelijking. Huurwoningen die voor vele duizenden guldens vertimmerd zijn tot "paleis in eigen ogen' vormen geen bijzonderheid.

Ook in de nieuwbouw komt men het verschijnsel van de zelfwerkzame (aspirant-)huurder tegen. Gedreven door de behoefte de huurlasten te beperken en de participatiemogelijkheden voor huurders te vergroten zijn een aantal woningcorporaties overgegaan tot de bouw van casco-woningen, waarbij de (aspirant-) huurder de af- of nabouw verzorgt, zoals de afwerking van vloeren, de plaatsing van binnenwanden, aanleggen van leidingen, aanbrengen van keuken- en sanitaire installaties en het plaatsen van trappen.

De hierbedoelde activiteiten, zowel bij nieuwbouw als in de bestaande voorraad, roepen nogal wat juridische vragen op. In hoeverre worden de door de huurder aangebrachte voorzieningen door de eigenaar van de woning nagetrokken? Mag of moet de huurder de aangebrachte voorzieningen bij het einde van de huurovereenkomst wegnemen?' Heeft hij, als de voorzieningen achterblijven, recht op vergoeding varn de waarde door de eigenaar? Or is hij gerechtigd de voorzieningen aan de opvolgende huurder over te doen? Deze vragen doen zich, naar het lijkt, in toenemende mate in de praktijk voor.

Het zijn niet de enige vragen: ook op administratief-rechtelijk vlak kan de zelfwerkzame huurder nog wel enige vragen oproepen. Kan ech bouwvergunning worden verleend voor een casco-woning? Wie moet de aangeschrevene worden als door huurderszelfwerkzaamheid een situatie is ontstaan die strijdig is met de bouwwoorschriften? Wat zijn de consequenties voor de individuele huursubsidie? Wat zijn de consequenties voor de geldelijke overheidssteun bij nieuwbouw en renovatie? Wat zijn de gevolgen op het vlak van huurvaststelling door de overheid en de gereguleerde huurverhoging?

Met het oog op de tijd en lettend op de ondertitel van de leerstoel die ik met het 
uitspreken van deze rede aanvaard, wil ik me heden beperken tot het privaatrechtelijke deel van de problematiek.

Achtereenvolgens komen aan de orde het zakenrechteljk begrip natrekking, de zakenrechtelijke vergoedingsregelingen, het wegbreekrecht van de huurder en de werplichting wan de huurder tot oplevering in de oorspronkelijke staat. Een en ander naar geldend en komend burgerlijk recht. Na een - vluchtige-blik in de belangrijkste vigerende standaard-huurovereenkomsten neem ik aan het slot van mijn betoog de gelegenheid te baat u enige gedachten en suggesties voor te leggen.

\section{NATREKKING; ONZELFSTANDIG WORDEN VAN EEN ZAAK}

Als een van de wijzen waarop eigendom, ook los van de wil van de verkrijger en de vroegere eigenaar, verkregen wordt noemt het BW de natrekking. Art. 643 BW bepaalt:

"Al hetgeen met eene zaak veremigd is, of met dezelve een ligchaam uitmaakt, behoort

aam den eigenaar, wolgens de regelen bij de volgende artikelen gesteld."

Een van de volgende artikelen is art. $656 \mathrm{BW}$ dat de natrekkingsregel uitwerkt voor bebouwd onroerend goed:

"Al hetgeen of een erf gebouwd is, behoort aan den grondeigenaar, mits het gebouwde met de grond vereenigd zij; behoudens de wijzigingen in artikel $658 \mathrm{en} 659$ voorkomende.' (Op laatstgenoemd artikel kom ik in paragraaf 4 terug.)

Aan deze natrekkingsregel ligt een "eenheidsbeginsel" ten grondslag, dat nergens in de wet is vastgelegd, maar in de civielrechtelijke doctrine wel degelijk cen vaste plaats heeft verworven: een te vergaande versnippering van eigendomsrechten zou, speciaal gelet op de rechten van eventuele schuldeisers, tot onwenselijke situaties leiden. Dit eenheidsbeginsel heeft ten onzent niet altijd gegolden. In het Oud-Hollands recht gold bijvoorbeeld dat de huurder eigenaar werd en bleef van hetgeen hij liet bouwen ${ }^{5}$, indien dit bouwen met toestemming van de verhuurder geschied was; betrof het niet het bouwen wan een geheel gebouw, maar het aanbrengen van zaken aan cen bestaand gebouw, dan was zelfs de toestemming wan de verhuurder niet vereist ${ }^{6}$. Ook nadat het huidige BW was ingevoerd, bleef de oude situatie, waarin, evenals bijvoorbeeld in het Franse recht ${ }^{7}$, de natrekkings regeling door pure wilsovereenstemming kon worden afgewend, een rol spelen. Ter illustratie wijs ik op cen uitspraak van de Rechtbank Amersfoort uit 1854. Daarin heet het dat de natrekkingsartikelen:

$\therefore$... hunnen toepassing missen in de gevallen waarin de eigenaar expresselijk, voordat het planten of bouwen heeft plaats gehad, van dit zijn regt wan natrekking afstand heeft gedtaan of wel zoodanig kontrakt heeft aangegaan, waarin die afstand als wan zelf ligt opgesloten.'

Dezelfde rechtbank overwoog verder:

"... dat zoodanige afstand van regten nergens is verboden en overeenstemt met den algemeenen regtsregel: unus quisque renutiare potest iis, quae prose introducta sunt ${ }^{8}$, in die artikelen woorgeschreven, van zoodanigen strikten aard heeft geacht, dat daaraan zelf niet zoude mogen gerenuntieerd worden door den belanghebbenden eigenaar 
van den grond, hoedanig verbod dan ook het ongerijmde resultat zou doen geboren worden, dat de eigenaar van den grond, zels al ware die verhuurd, steeds eigenaar zoude zijn van den oogst, zonder dat de huurder het regt zoude hebben dien oogst, ofschoon door hem gezaaid en bewerkt, te maajien."

Ook de Hoge Raad toonde zich in de vorige ceuw rog a anhanger van de (Franse) leer, volgens welke degeen die met eigen materiaal en met toestemming van de eigenaar bouwt op andermans grond, eigenaar wordt van het gebouwde"

'... dat die beschouwing van de Rechtbank alleszins juist is, darar er geen de minste grond is om aan te nemen dat het beginsel, uitgedrukt in de art. 626 en $656 \mathrm{BW}$, tot de openbare orde zou behoren, zoodat daarvan bij overeenkomst niet zou mogen worden afgeweken, mar dat het integendeel den grondeigenaar volkomen vrijstaat om an een ander vergunning te verleenen om op zijn grond te bouwen of te beplanten, met dat gevolg ,dat die andere eigenaar wordt van het door hem gebouwde of geplante, ... " .

Eerst bij het zgn. Arena-arrest van 4 december $1903^{11}$ werd, eens en vooral naar het lijkt, beslist, dat afwijking van het natrekkingsbeginsel slechts mogelijk is door het vestigen van een zakelijk recht, zoals exn recht van opstal (na afwijkende conclusie van Advocaat-Generaal Ort):

¿... dat alleen dan, wanneer bleek dat de gefailleerde had wat zij blijkt te missen - $\mathrm{nl}$, een zakelijk recht als dat van opstal, door hetwelk eene uitzondering op den rechtsregel van art. 656 woormeld kan worden geschapen - het eigendomsrecht van den grondeigenar op hetgeen hij Arena had veroorloofd te bouwen zou zijn witgesloten geworden." Daarmee is weliswaar de eigendomsverkrijging als systeem volledig gesloten geraakt, nog niet is uitgemaakt wat nu precies geacht moet worden met de grond verenigd te zijn. Wat dus onder de natrekkingstegel valt wanneer een (roerende) zaak bestanddel wordt van een onroerende zaak. Ook hier geeft de jurisprudentie een boeiende ontwikkeling te zien. Kort na het Sleepboot-Egbertha-arrest (HR 26 maart 1936, NJ 1936, 757) stapt de rechter ook ton aanzien van onroerend goed af van de eis dat, will wan natrekking sprake zijn, de nagetrokken zaken aard en nagelvast moeten zijn bevestigd. Beslissend is, of volgens in het maatschappelijk verkeer bestaande opvattingen een zaak wezenlijk bestanddeel is van het onroerend goed, de hoofdzaak. Een ollestook-installatie in een klooster valt erdan, i.e. 1937 - nog nilet onder:

'.. dat huurders van gebouwen de hun toebehoorende, in die gebouwen aangebrachte oliestookinrichtingen steeds in haar geheel medenemen, waartegen nimmer bezwar wordi gemaakt." 12

Ruim tien jaar later blijven een los bad, vaste wastafels en cen geyser gespaard voor natrekking:

'... dat, waar het hier gat om een los bad, een geyser en vaste wastafels, die als regel als massaprodukten in den handel zijn en die mitsdien over het algemeen zo zijn geconstrueerd, dat zij in ieder onroerend goed gebruikt kunnen worden, moet worden angenomen, ... dat zinn niet specialal dienstbaar waren aan het onderhavige onrotend goed, terwijl het huis bewoonbaar bleef zonder de aanwezigheid van die voorwerpen." 13

Waar deze woorwerpen nog luxe en uniek zjin is het, in het maatschappelijk verkeer gebruikelijk ze mee te nemen. De rechter stelt ze vrij van natrekking. In 1953 is de progressie echter zo ver voortgeschreden, dat althans in cen bedrijfsgebouw, de c.v.-installatic en het sanitair niet langer an de greep van de natrekking ontkomen: 
".. dat cen dergelijke moderne fabriek ondenkbast is zonder centrale verwaming, licht-en krachuleidingen, waterle ding en sanitair en thet Hof, rekening houdend met alle woonelde feiten, van oordeel is, dat alle hierbowen opgesomde goederen con de overige in de daguarding genoende zaken . . zodanig met het onroerend goed verbon. den zinn, dat zij daarmede en entheid zijn gaan vormen in de zin van art. $643 \mathrm{BW}$, zoals dat hierboven mader is geinterpreteerd. "14

Boeiend in dit arrest is de twijfelachtige positic van de vaste wastafel:

"... dat het wellicht logisch niet verantwoord is om een vaste wastafel niet als tot het onroerend goed behorende te beschouwen en de pot van een WC wel, aangezien immers de werbinding met het huis bij beiden identiek is, maar dat de verkeersopvatung nu eenmal niet altijd logisch is, doch niettemin het criterium blift, dat in rechte behoort te worden toegepast."

Vanaf zijn hoge post beschouwt het Hor het matschappelijk verkeer diep beneden hem, en schudt zijn hoofd. Maar de lezer voelt dat het met die vaste wastafels niet lang meer kan duren!

En inderdaad: bij de cassatie wan het hierbedoelde arrest wan het Hof's-Hertogenbosch, trekt de Advocaat-Generaal Mr. Eggens al in twijfel of vaste wastafels wel buten bereik wan de natrekking kunnen blijen. De "opvattingen in het maatschappelijk verkeer" worden door hem verfijnd in de volgende passage ${ }^{15}$ :

'Het komt mijl voor dat het Hor met deze overweging heeft aangegeven, dat het betrokken nieukgebouwd, - modern - fabrieksgeboww dusdanig was geconstrueerd dat de betrokken installaties een zodanig onderdeel zijn gaan vormen dat zonder deze de constructie van het gebouw als - modern - fabrieksgebouw niet voltooid en volledig mocht heten, zodat en omdat het zonder deze installaties zijn kwaliteit van - modern - fabrieksgebouw niet zou bezitten (zoals b.v. "moderne gemakken" tot onzelfstandige onderdelen van een moderne villa gerekend zullen - kunnen - worden, behorende tot de constructie darvan)."

Belangrijk is, dat dit Stafmateriaal-arrest, na Eggens" conclusie, drie natrekkingsgronden naast elkaar zet:

1. aard-en nagelvaste zaken;

2. niet aard-en nagelvaste zaken die bestanddeel zijn;

3. niet aard-en nagelvaste zaken die geen bestanddeel zijn, maar genoemd worden in art. $653 \mathrm{BW}$ (bij woonhuizen zijn dat 'spiegels, schilderijen en andere sileraden, vastzittend op hout- of muurwerk".

Sinds 1953 hebben de ontwikkelingen niet stilgestaan; het uitrustingsniveau wan woningen is sterk verbeterd. Niet langer zijn alleen villa's van 'moderne gemakken'voorzien. Vrijwel alle nieuwe of gerenoveerde woningen beschikken vandaag de dag over een hoog uitustingsnivea , bevattend centrale verwarming, vaste wastafels, losse kasten, bad of douche, warm en koud stromend water, een keukeninstallatie en cen of meer toiletten. Overeenkomstig het verhoogde uitrustingsniveau is de "verkeersopvatting' geävolueerd: hoe demontabel ook, al deze onderdelen behoren tot de standaarduitrusting van een woning. Ze zijn bestanddeel van de woning, ofliever van het onroerend goed. Ze worden nagetrokken ${ }^{16}$.

De theorie is inmiddels nuet onverdeeld gelukkig met de als een olievlek werkende "verkeersopvatting". Niet de geringste juristen hebben zich tiegen de werking van de natrekkingsregel zoals door de rechter geduid, verzet. Zo heeft Paul Scholten 
op verschillende plaatsen kritiek geuit ${ }^{17} ; \mathrm{J}$. Drion wees in 2 ijn noot onder het Stafmateriaal-arrest op de zwakte van het criterium ${ }^{18}$. J.H. Beekhuis ${ }^{19}$ moemde de verwijzing naar de verkeersopvatting een dooddoener.

Suyling ${ }^{20}$ was de eerste die, met behulp van een alternatief criterium de werking van de natrekkingsregel poogde te beperken (natrekking alleen bij organische, miet bij anorganische verbindingen), gevolgd door Beekhuis ${ }^{21}$ (beslissend voor natrekking is het antwoord op de vraag of de hoofdzaak zonder het bestanddeel praktisch aan haar economische en maatschappelijke bestemming zou kunnen beantwoorden). Van der Grinten ${ }^{22}$ stelde het 'eigen redelijk oordeel.' van de rechter in de plaats van het criterium "verkeersopvatting"; daarbij moet hij bezien of een bijzaak na afscheiding van de hoordzaak haar economische waarde behoudt. Een belangrijke poging tot herformulering van natrekkingcriteria is gedaan door Heyman ${ }^{23}$. Naast de onontkoombare natrekking wan zaken die niet zonder betekenende beschadiging of vernictiging van economische waarden kunnen worden afgescheiden, introduceert hij zijn 'gerelativeerde verkeersopvatting", die, vertaald naar het onderwerp en de achtergrond van deze bijdrage, hierop neerkomt: lhuurder brengt cen badkuip aan in de gehuurde woning; tegenover de wederpartij (eigenaar-verhuurder) vindt geen natrekking plaats; derden (b.v. koper of hypotheekbank) kunnen zich echter wel op natrekking beroepen. Omtrent de vraag wat, volgens verkeersopvatting, als bestanddeel van een (onroerende) zaak moet worden aangemerkt, laat Heyman zich evenwel niet wit. Belangrijk is echter zijn constatering dat (in de literatuur) cen sterke tendens bestaat de werking van de natrekkingsregel to beperken. De vraag dringt zich op of en hoe de wetgever bij de samenstelling van de boeken 3 en 5 NBW deze tendens heeft begrepen en gewaardeerd. Hieronder (par. 8) kom ik op deze vraag terug.

\section{ONROEREND WORDEN VAN EEN ZAAK}

Van de natrekkingsregel moet onderscheiden worden het vraagstuk hoe en wanneer een zatak geacht moet worden onroerend te zijn geworden. Hoewel het onderscheid in de praktijk niet vaak (goed) gemaakt wordt, is het nuttig erop te wijzen, dat natrekking van een zaak op zichzelf niet betekent dat die zaak onroerend wordt, terwijl, naar lange tijd is volgehouden, het onroerend worden van een zaak niet per definitie de eigendom doet overgaan op de eigenaar van de grond. De vraag of een zaak onroerend is (geworden) is vooral van belang voor de hypotheeknemer en de fiscus (overdrachtsbelasting e.a.). Vanzellsprekend gaan, in verband met deze bijdrage, de gedachten wit naar door de huurder aan een onroerend goed aangebrachte voorzieningen: kan de hypotheeknemer zich ook op deze woorzieningen verhalen? Wordt, bij ejgendomsoverdracht de overdrachtsbelasting mede over de aangebrachte voorzieningen gerekend?

De vraag of iets geacht moet worden onroerend te zijn door bestemming is enkele malen aan de rechter voorgelegd. De HR heeft een aantal malen de eis gesteld dat de zaken (gebouwen en voorwerpen) zich door onderling met elkaar overeenstemmende eigenschappen voor soortgelijke gcbouwen en voorwerpen 
moeten onderscheiden en dat de voorwerpen zich zo moeten aanpassen aan het bepaalde gelbouw, dat zij het kenmerk vertonen tot een blijvend gebruik daaraan te zijn verbonden ${ }^{24}$. Reeds in 1954 heeft $J$. Drion het criterium van 'pasklaarheid", het blijkbaar bij elkaar horen van gebouw en voorwerp, op opmerkelijke wijze geinterpreteerd ${ }^{25}$. Ik citeer:

"Vooral sedert de moderne standlaardbouw is deze vraag van praktisch belang. Zijn bijwoorbeeld niet-nagelvaste ingebouwde keukenkastjes onroerend door bestemming, indien deze in alle huizen in de omgeving evenzeer passen? Naar ik meen moet deze vraag bevestigend worden beantwoord, omdat in deze gevallen de bestemming tot een blijvend gebruik naar buiten blijkt en daarbij irrelevant is of de hulpzaken ook zouden passen in de vele andere identicke woonhuizen.'

'Onroerend door bestemming' lijkt, Drion lezend, een ontwikkeling in de breed te te gaan doormaken die vergelijkbaar is met die wan de natrekkingsregel. Het opmerkelijke is, dat dit in de praktijk niet is gebeurd. Integendeel, thet onroerend zijn door bestemming wordt in de rechtspraak, enkele uitzonderingen daargelaten, tot op de dag van wandaag eng geinterpreteerd. Sinds, bij arrest van 31 mei $1932^{26}$ de HR heeft uitgemaakt, all thans volgens de meeste schrijvers ${ }^{27}$, dat van onroerendheid door bestemming alleen sprake kan zijn als een roerende zaak door de eigenaar ervan met diens onroerende zaak is verenigd ${ }^{28}$, is de jurisprudentie voor het hier aan de orde zijnde onderwerp maar van beperkte betekenis. Daarom volsta ik met aan te duiden dat als criterium bij herhaling het 'bijzonder verband' wordt gehanteerd tussen de voormalige roerende zaak en de onroerende zaak ${ }^{29}$ waardoor de zaak tot het 'wezen" van het onroerend goed is gaan behoren. Wel zijn er uitzonderingen, waarbij wat soepeler tot onroerendheid door bestemming wordt beslist ${ }^{30}$, voornamelijk kijkend naar wat de eigenaar wille, maar de enge opvatting overheerst. Dat komt fraai tot uitdrukking in een uitspraak van de Rechtbank "s-Hertogenbosch ${ }^{31}$, waarin een keukeninstallatie als roerende zaak werd aangemerkt. Vastgestelld kan worden dat, ingevolge de meest recente jurisprudentie een keukeninstallatie niet onroerend is, doch we] wordt nagetrokken ${ }^{32}$. Voorwaar een verwarrende situatie!

Voor een huurder die, in zelfwerkzaamheid, woorzieningen aanbrengt aan het gehuurde zou dit betekenen, dat de eigendom door de verhuurder/eigenaar al snel wordt nagetrokken (behoudens huurders rechten uit $1603 \mathrm{BW}$, waarover straks), maar dat hij er b.v. tegenover de hypotheeknemer vrij gemakkelijk in slaagt om door hem aangebrachte voorzieningen buiten een executoriale verkoop te houden. Tegenover derden (hypotheeknemer) wordt de huurder met zijn voorzieningen dus beschermd, tegenover de eigenaar delft hij het onderspit. Dit is een situatie die ongeveer 180 graden afwijkt van het door Heyman voorgestane systeem (zie par. 2), waarbij juist de eigenaar een stapje terug moet doen, maar waraiji de derde wordt beschermo.

\section{VERGOEdING VAN DOOR HUURDER AANGEBRACHTE VOORZIENINGEN}

Dat door de huurder aangebrachte voorzieningen, behoudens in geval van vestiging van een zakelijk recht als opstal, door de eigenaar worden nagetrokken will 
natuurlijk nog niet zeggen dat de eigenaar niet tot enige vergoeding gehouden zou zijn jegens degene op wiens kosten de voorzieningen zijn aangebracht.

De artt. 658 en $659 \mathrm{BW}$ bevatten een, voor de onderhavige studie, interessante vergoedingsregeling voor het bouwen op (aan) andermans onrocrend goed. Sa* mengevat kom thet in deze artikelen verwoorde systeem op het volgende neer:

$\mathrm{Bij}$ het bouwen op andermans grond heeft de eigenaar de keus tot wegnemen te dwingen (op kosten van de maker) of de waarde van de bouwstoffen en het werkloon te vergoeden. In het specifieke geval waarin door een bezitter te goeder trouw op andermans grond gebouwd is, mag wegnemen niet worden gevorderd; de cigenaar heeft dan de keus tussen vergoeding van bouwstoffen en werkloon of vergoeding van de meerwaarde van het erf.

In de jurisprudentie is de toepasselijkheid van deze artikelen ingrijpend beperkt. De HR heeft bepaald dat deze regeling niet van toepassing is als blijkt dat gebouwd is door iemand, die de grond onder zich heeft gekregen krachtens een contractuele verhouding met de eigenaar ${ }^{33}$ :

'... dat de bepalingen der artt. 658 en 659 enkel gegreven zijn voor het geval, waarin de betrokken personen op geen andere wijze met elkaar in a anraking zijn gekomen dan doordat de een heeft gebou wd op het terrein van den ander, en dat zij niet bestemal zijn gevallen te regelen, waarin degeen, die met eigen materiaal op andermans grond bouwt, reeds tot den grondeigenaar in een rechtsbetrekking ten opzichte van den grond staat."

Al veel eerder ${ }^{34}$ had de Rechtbank Rotterdam in ieder geval de huurder het recht ontzegd zich op deze artikelen te beroepen:

"... daar dit artikel slechts voor den bezitter geldt, in ieder geval niet voor den huurder, woor wien in art. 1603 BW een bijzondere bepaling is gegeven... ${ }^{35}$

Op de merkwaardigheid van deze voor huurders nadelige uitzonderingsgedachte kom ik in paragraaf 5 terug.

De andere vermeldenswatardige beperking van de toepasselijkheid van de hierbedoelde artikelen is gelegen in de eis dat het gebouwde gerealiscerd moet zijin door iemand die bezitter of houder van de grond is. Dit standpunt, neergelegd in het beroemde arrest Quint-te Poel ${ }^{36}$, heeft nogal wat stof doen opwaaien in de discussie over ongegronde verrijking; voor het hier behandelde onderwerp is de laatstgenoemde beperking echter niet van direct belang. Volstaan kan hier worden met de vaststelling dat de bezitter of houder van een onroerend goed bijna altijd een contractuele relatie met de eigenaar heeft, zodat men weer bij de eerdergenoemde beperking (het vereiste van een contractuele relatic) uitkomt. Of die beperking terecht is wil ik hierna bezien aan de hand van een nadere bestudering van het 'wegbreekrecht'.

\section{WEGBREEKRECHT}

'Art. $1603 \mathrm{BW}$ is een bepaling, welke den uitlegger hoofdbreken kost en waarvan geen de werking ten volle heeft uitgetekend.'

Aldus prof. Mr. Ch. Petit in 1954 $4^{37}$. Deze tweeledige stelling is dubbel juist; niettemin wil ik pogen de werking van dit merkwaardige, geruisloos ons BW binmengeslopen artikel 'uit te tekenen'. En liefst ten volle! 
Om malr wat provocerend te beginnen: de diverse uitspraken en artikelen, betrekking hebbend op het wegbreekrecht gelezen hebbend, heeft bij mij de mering post gevat dat dit artikel al bijna anderhalve eeuw verkeerd wordt begrepen en toogepast. Grijpen we terug naar de hierboven aangehaalde uitspraak van de Rechtbank Amersfoort van 185438. Daarin werd-kort weergegeven-gesteld, dat de natrekkingsregel bij overeenkomst kan worden doorbroken, en het dictum vervolgt:

‘. dat derhalve uit art. $160 \$$, als ook uit den aard en natur van het hurcontract in het algemeen voortvloeit, dat de verhuurder, zoolang de huur duurt, evenmin eigenaar is van de gebouwen, door den huurder op het gehuurde gesteld, als hij eigenaar is van diens oogst, doch daarvan eerst eigenaar wordt wanneer de huurder bij het eindigen van der huurtijd een en ander niet wegneemt.'

op grond van de opvatting dat de natrekkingsregeling contractueel opzij kan worder gezet, wordt bepaald dat 1603 BW derogeert aan 658/659 BW. Zoals hiervoor al gesteld, werd in 1903 het eerste deel van deze opvatting door de HR verlaten; het merkwaardige is echter dat het tweede deel van de opvatuing - $1603 \mathrm{BW}$ derogeert aan $658 / 659 \mathrm{BW}$ - ondanks de nauwe samenhang in stand is gebleven en een eigen leven is gaan lciden. Men vind dat al in een uitspraak van de Rechtbank Rotterdam van 192439:

'... dat gedaagde zich ten onreclate op art. $658 \mathrm{BW}$ ' beroept, daar dit artikel slechts voor den bezitter geldt, in ieder geval niet voor den huurder, woor wien in art. 1603 BW een bijzondere bepaling is gegewen evenăls voor den opstaller, den erfpachter en vruchtgebruiker in de artt. 762, 772 en 826 en 827 BW.'

Art. $1603 \mathrm{BW}$, cen stukje (regelend) verbintenissenrecht zet de bepalingen van het zakenrecht inzake eigendonswerkrijging opzij. Dat heeft de jurisprudentie ook na de hiergenoemde uitspraak nog diverse malen gesteld ${ }^{40}$. Daarmee verliest de huurder, naar het lijkt, definitief aanspraak op enige vergoeding in geval hij aangebrachte voorzieningen laat zitten. Het opmerkelijke feit doet zich voor dat dit gevolg van de hierbedoelde theoric, hier en daar vervolgens opduikt als oor zaak: omdat de huurder geen aanspraak kan maken op een vergoedingsregeling heeft hij het wegbreekrecht van 1603 BW gekregen! Het duidelijkst op dit punt is Pitlo 4 :

'Nergens geeft de wet aan de huurder recht op vergoeding voor wat hij aan het gehuurde ten koste heeft gelegd. Aangezien nu de verhuurder door natrekking eigenaar is van de door de huurder aangebrachte werken, heeft de huurder het recht af te breken en tot zich te nemen al wat hij heef aangebracht, mits het gehuurde hiervan geen beschadiging ondervindt."

Verwant aan deze opvatting is de overweging uit het eerdergenoemde (zie noot 36) arrest Quint-te Poel.

... dat echter blijkens de artt. 1658 en 1603 van den grondeigenaar niet kan worden gevergd, dat hij door betaling van een geldsbedrag de verrijking ongedaan maakt die hij heeft genoten doordat de bezitter of de huurder van den grond werken heeft aangelegd."

Van belang is ook de conclusie van A.G. Wijnveldt bij HR 30 april 1948, NJ 1949, 253 (Smit-Amsterdamse Huizenhandel, zie noot 33), Voor de door hem verdedigde - en door de HR overgenomen - opvatting dat art. $1603 \mathrm{BW}$ als lex specialis derogeert aan de artt. 658/659 BW beroept hij zich op Scholten en Suy- 
ling. Gewoonlijk versterkt een beroep op deze eminente juristen het betoog, hier is echter het tegendeel het geval. Scholten (en Suyling) hanteerden immers de opvatting dat bij (huur) contract van de zakenrechtelije (natrekkings) beginselen kon worden afgeweken. Waar deze opvatting door de juridische wereld niet is overgeromen, kan hun opvatting niet als argument diemen voor de lex specialistheorie die kennelijk nog steeds wordt aangehangen.

Duidelijk moge zijn, dat de gangbare theorie inzake art. $1603 \mathrm{BW}$ nadelig is voor de huurder, wat hem een redelijke schadevergoeding op voorhand wordt geweigerd 'omdat hij mag wegbreken', resp. waarbij 'hij mag wegbreken omdat hij geen schadevergoeding krijgt'. Naar mijn overtuiging is de hierbedoelde band ten onrechte gelegd en produkt van het "historisch misverstand", waarbij in $1854^{42}$ het artikel tot zakenrechtelijke proporties werd opgeblazen en in relatie werd gebrach met aangebrachte veranderingen en verbeteringen aan het onroerend goed. De zakenrechtelijke proporties zijn later aanzienlijk geslonken, de relatie is aanwezig gebleven. Niettemin biedt noch de tekst van de wet, noch de plaats van het verbintenisrechtelijke art. $1603 \mathrm{BW}$, noch de wetgeschiedenis enige aanleiding voor de weronderstelling dat de hierbedoelde band werd beogd. Integendeel, het artikel is niet anders dan een uitwerking van de "oorspronkelijke staat" - gedachte: gegeven de verplichting het gehuurde in de oorspronkelijke staat op te leveren wordt de huurder bij het einde van de huur in de gelegenheid gesteld, door afbreken en naar zich nemen die oorspronkelijke staat te herstellen $^{43}$. Hij wordt in de gelegenheid gesteld op de valleep aan zijn verbintenisrechtelijke verplichting te voldoen.

Met natrekking en - ruimer-zakenrecht heeft deze bepaling op zichzelf niets te maken. Er is dan ook geen enkele reden om, indien een door een huurder aangebrachte verbetering door natrekking eigendom is geworden van de eigenaar van het on roerend goed van toepassing van de daarvoor geldende algemene regelingen in artt. $658 / 659 \mathrm{BW}$ af te zien.

\section{DE OPLEVERING DOOR DE HUURDER IN DE OORSPRONKELIJKE STAAT}

In de literatur wordt er over het algemeen van uitgegaan datt de artt. 1598 en 1599 , in hun onderling verband (en in verband met art. 1603 BW) bezien, betekenen dat de huurder het gehuurde moet teruggeven in dezelfde staat warin hij het heef ontvangen, waarbij tot op tegenbewijs door de huurder, de oorspronkelijke staat geacht wordt een goede te zijn geweest. Ook hier is weer sprake van een geleidelijk in de rechtspraktijk ingesleten misverstand: in de genoemde artikelen staat immers niet wat men er kennelijk zo graag en veelvuldig in leest. Art. 1598 gaat uit van de situatie waarin aan het begin van de overcenkomst een beschrijuing van het verhurude is opgemaakt. Als dat zo is, dan moet aan het einde van de overeenkomst in de beschreven toestand worden opgeleverd 'met uilzondering van hetgeen door ouderdom of door onvermijdelijke toevallen vergaan of van waarde verminderd is". Art. 1599 stelt dat, indien zo'n beschrijving niet is opgemaakt, de huurder geacht wordt het gehuurde in goede staat van ondertioud te hebben aan- 
vaard en verplicht hem het gehuurde in diezelfde statat (i.e. van onderhoud) op te leveren als hij vertrekt. Indien er een samenhang bestaat tussen de hiergenoemde artikelen dan ligt het woor de hand die samenhang te zien in de veronderstelling dat beide artikelen het oog hebben op de onderhoudstoestand aan het begin en aan het einde van de huurovereenkomst. Los van deze veronderstelling is het nuttig vast te stellen dat de artikelen toevoegingen en verbeteringen niet verbieden; de oorspronkelijke staat (van onderhoud) kan aangemerkt worden als de bodem van de opleverings(onderhouds-) kwaliteit. Daar bovenop komende objecticve verbeteringen zijn "meegenomen" en maken de staat (van onderhoud) bij oplevering niet slechter, maar veeleer beter. Maar zelfs alls men van de-mijns inziens onjuiste - veronderstelling uitgaat dat een huurwoning er aan het einde van de huurovereenkomst nog precies zo uit moet zien als aan het begin doet zich nog de vraag voor of goede trou w c.q. redelijkheid en billijkheid een verhuurderseis tot het op huurders kosten wegnemen van objektieve verbeteringen verdraagt c.q. verdragen ${ }^{44}$.

Intussen heeft de gedachte van de oorspronkelijke staat in zijn meest absolute vorm in de rechtspraktijk tot absurde situaties geleid. Nog steeds wordt op grote schaal van de vertrekkende huurder geëist dat hij, op zijn kosten, een af- of aanvoerleiding van een wasmachine, wand- of vloerbekleding (isolatie), extra sanitaire voorzieningen etc. verwijdert, soms zelfs als de opvolgende huurder al met de wijzigingen ten opzichte van de oorspronkelijke staat heeft ingestemd. Nog steeds wordt de huurder in vele huurcontracten of huurreglementen verplicht alle veranderingen ongedaan te maken en het gehuurde in oorspronkelijke staat terug te brengen. Nog steeds word op grote schaal door verhuurders, met name ook in de sociale sector, bij het einde van de huur een dergelijke oplevering in oorspronkelijke staat daadwerkelijk geëist. En nog steeds zijn er rechters die een dergelijke eis toewijzen.

Een pakkend voorbeeld wordt grevormd door de uitspraak van de Kantonrechter te Gouda ${ }^{45}$. In diens uitspraak werd de gedachte van de oorspronkelijke staat in zijn meest absolute vorm genadeloos toegepast. Het betrof een door de huurder aangebrachte, isolerende wandbekleding van schoonmetselwerk tegen een uitzonderlijk koude buitenmuur. Een hele verbetering! Waar tussen partijen geen bijzondere bedingen golden, kon de Ktr. de artt. 1598, 1599 en 1603 onverkort toepassen. Des te opmerkelijker is zijn overweging:

'O., clat men zich zou kunnen afvragen, of een verhuurder, die door een huurder op eigen kosten aangebrachte bescheiden kwalitatieve verbeteringen van het goed, welke de waarde van het gehuurcle noch de verhuurbaarheid verminderen - de opvolgende huurder wilde de wand accepteren - en die evenmin onesthetisch zijn, van hoedanige verbetering ten deze sprake is, zinvol handell door die toevoegingen weer te laten verwijderen en of zodanig handelen ten opzichte van de huurder nog wel als te goeder trouw kan worden aangemerkt, maar naar Ons oordeel de uitoefiening van het wettelijk recht van de verhuurder om herstel in de oude toestand te bekomen, door de werking van de goede trouw niet wordt beperkt, ook niet in die gevallen, waarin het nut van zodanig herstel niet valt in te zien;

O., dat, zolang de Wetgever terwake van de onderhavige materie geen nadere regelen stelt, huurders gehouden blijven tot teruggave wan het gehuurde goed in dezelfde staat, 
waarin zij het hebben aanvalard, zelfs al mocht het resulltaat daarvan uit cen oogpunt van volkshuisvesting ongewenst zijn (bijw. het wegbreken van een door de huurder aangebrachte douchegelegenheid).'

Als de uitspraak - en met name de laatstwermelde overweging - al is bedoeld als een noodkreet in de richting van de wetgever, dan moet worden wastgesteld dat deze (nog) niet is verstaan ${ }^{46}$. Zoals wij hierna nog zullen zien heeft de gedachte van de oorspronkelijke staat in de meest absolute zin, een belangrijke rol gespeeld bij de formulering van art. 7.4.3.3. van het Ontwerp NBW. Vooralsnog zullen we het in de praktijk moeten hebben van rechters die-zoals dat hoort-de goede trouw ook op deze kontraktuele relatie van toepassing achten. Een eerste uiting van toepassing van dit beginsel treffen we aan in een uitspraak van de $K$ tr. Amsterdam ${ }^{47}$ :

'O., dat nu ... eiser de woning heeft verbeterd door datarin vloerbedekking van vinyl in de woonkamer aan te brengen en cen waterleiding in de keuken, en deze, zonder aanspraak te maken op vergoeding heeft achtergelaten, gedaagde geen recht en reden had de waarborgsom te verrekenen met door haar gepretendeende evenwel niet toewijsbare kosten, ...'.

Deze uitspraak krijgt een waardig opvolger in Rechtbank 's-Hertogenbosch 198248:

¿.. dat Van der Breggen voorts niet verplicht was voren bedoelde - bevoegd aangebrachte - bekleding en stoffering bij de beëindiging van de huur te verwijderen en het gehuurde in de oorspronkelijke vorm op te leveren, aangezien voor cen dergelijke verplichting slechts een rechtsgrond bestaat, indien het gehuurde door het aclaterwege blijven daarvan niet in goede staat zou worden opgeleverd (art. 1599 BW), dan wel zou zijn beschadigd (art. 1600 BW).'

Deze uitspraak gaat niet uit van mijn hierboven genoemde veronderstelling dat de artt. 1598/1599 slechts het oog hebben op de oorspronkelijke resp. goede stat van onderhoud; wel sluit zij aan bij mijn als tweede geuite veronderstelling dat de goede staat-bepaling van 1599 BW de bodem aangeeft van de staat waarin opgeleverd moet worden, doch niet beoogt verbeteringen/voorzieningen door de huurder tegen te gaan. De eerder besproken uitspraak van de Ktr. Amsterdam lijkt een direkte toepassing van het beginsel der goede trouw in contractuele verhoudingen.

\section{DE NIET-VERGOEDING VAN DE HUURDER NADER BESCHOUWD}

Hiervoor (zie paragraaf 6) schetste ik al hoe de huurder buiten de algemene vergoedingsregels is geraakt en hoe - ten onrechte - art. $1603 \mathrm{BW}$ de plaats is gaan innemen van een bijzondere vergoedingsregeling: géén vergoeding want de huurder mag wegbreken. De vertrekkende huurder staat dus met lege handen. Normaal gesproken mag hij blij zijn dat hij niet ook nog de verwijdering van de door hem aangebrachte voorzieningen hoeft te betalen. Op grond van het BW hoeft hij op meer niet te rekenen. Aan het einde van zijn huurovereenkomst hoopt de huurder dan ook in contact te kunnen komen met zijn opvolger en hem bereid te vinden de veranderingen te aanvaarden. Dat gebeurt veelal door het overnemen van de voorgaande huurders' verplichting tot herstel in de oorspron- 
kelijke toestand. Vaak word daarbij ool geprobeerd aan de opvolgende huurder cen bedrag te ontutselen voor "overnamekosten" voor door de voorgaande huurder 'onverplicht aangebrachite geriefsverbeteringen'. Een opvolgende huurder dient zich ernstig te beraden voordat hij voor aanvaarding in de afwijkende toestand tekent of betaalt. Hij moet maar afwachten of zijn opvolger op zijn beurt bereid zal zijn tot cen dergelijke aanvaarding en overname. Bovendien leert de praktijk dat valk met een botte weigering op het aanbod van de voorgaande huurder kan worden gereageerd, zonder dat dit leidt tot het wegnemen van, vaak moeilijk te verwijderen of te vervangen, voorzieningen ${ }^{49}$. Menige bruikbare voorziening kan een opvolgende huurder aldus om niet geworden, zonder dat hij enige verantwoordelijkhcid voor verwijdering t.z.t van genoemde voorzieningen heeft aanvaard. Maar fundamenteler is, dat de opvolgende huurder een gerede kans loopt de overnamekosten twee maal te moeten betalen: eenmaal aan diens voorganger, en eenmaal aan de verhuurder. Dat bleck uit een uitspraak van de Ktr. Amsterdam van 13 julli 1982 . Het betrof hier een geval waarin de opvolgende thuurder aan zijn voorganger $f 17.500,-$ overnamekosten had betaald. Eenmaal gezeten zag de nieuwe huurder zich geconfronteerd met een aanzienlijke verhoging van het puntentotal ingevolge de Huurprijzenwet woonruimte, als gevolg waarvan de huurprijs van ruim f 350 ,- bijna werd verdubbeld tot 700 ,per maand. De verbeteringen, waaraan de verhuurder niets ten koste had gelegd, leverden 49 extra punten op ingevolge de bijlage bij het Huurprijsbesluit Woonruimte; zij waren immers door accessieve eigendomsverkrijging eigendom geworden van de eigenaar en dus konden zij meetellen in de puntenwaardering ingevolge de Huurprijzenwet. In mijn wat boze noot onder deze uitspraak schreef ik:

'En dat, terwijl al vanaf 1838 iedere betaling een schuld doet veronderstellen en artikel 1395 BW derhalve stelt, dat hetgeen zonder verschuldigd te zijn betaald is kan worden teruggevorderd. Het lijkt echter niet reëel te veronderstellen, dat een dergeliijke procedure, door de nieuwe huurder aangespannen tegen zijn voorganger, enige kans van slagen zou hebben."

Maar zic: de teleurgestelde huurder wendde zich kort daarop tot zijn voorganger en worderde met succes (een groot deel van) het betaalde bedrag ad 1 17.500,terug; op grond van onverschuldigde betaling. Dat viel dus mee. Nog mooier is het volgende: in mijn aantekening naar aanleiding van $\mathrm{Krt} .13$ juli 1982 stelde ik ${ }^{\text {so: }}$

"Er is alle reden artikel 15 Huurprijzenwet zodanig aan te passen dat duidelijk wordt dat ook de volgende huurder gevrijward blijft van een extra aanslag in de puntenwaardering in vertband met een niet door de verhuurder verzorgde (betaalde) gepresteerde kwaliteitsverbetering. In afwachting daarvan zou artikel 15 lid 3 analoog op de opvolgende huurder moeten worden toegepast.'

Ik werd op mijn wenken bediend. Hetzelfde Kig. Amsterdam oordeelde op 23 november $1983^{51}$, naar aanleiding van een vordering uit onverschuldigde betaling van cen opwolgende huurder (voor cen keukenuitrusting, nieuwe muren, gestukadoorde plafonds, verhoogde vloeren, uitbreiding elektrische installatie, schilder-, wit- en behangwerk) tegen diens voorganger ad ( 5.300,-, dienovereenkomstig. Kennelijk geïnspireerd door de hiervoor behandelde uitspraak stelde de opvolgende huurder dat het hier geen legale transactie betroffen kon hebben, 
aangezien het onroerend goed, inclusief verbeteringen, aan de eigenaar toebehoorde. De Ktr.: "Waarom het deswege niet legaal zon kunnen zijn ontgat ons". In de nadere beschouwing van deze uitspraak komt de aap uit de mouw:

'Die mening omtrent de niet-redelijkheid tow de opkomende huurder kan mede beinwloed zijn door het standpunt dat wordt ingenonen m.t.t. art. 15 lid 3 HPW nl. in hoeverre de voorzieningen, welke een (voorgaand) huurder onverplicht heeft aangebracht, waardoor het woongerief geacht kan worden te zijn gestegen, al dan niet doorwerken in de huurprijs. Acht men het daar bepaalde niet toepasselijk t.a.x. voorzieningen door een voorgaande huurder getroffen, zelfs indien de opvolgende huurder die voorzieningen tegen betaling heeft 'overgenomen' ... dan zal die niet-redelijkheid wellicht eerder worden aangenomen dan in het geval dat met Ons analogische toepassing van art. 15 lid 3 HPW mogelijk wordt geacht.'

Daarmee was de eerste, door mij bepleite, analoge toepassing van art. 15 lid 3 Huurprijzenwet een feit. De overgang van het recht ook als opvolgende huurder gevrijwaard te blijven van huurverhoging i.v.m. de aangebrachte voorzienin gen/verbeteringen vormt dan de economische tegenprestatie voor de te betalen overnamekosten. Maar het blijft, zowel voor komende als voor vertrekkende huurder, een wankele basis!

\section{NATREKKING, WEGBREEKRECHT EN VERGOEDINGSREGELING NAAR KOMEND RECHT}

Het bezien van de positie van de huurder naar NBW lijkt rijkelijk prematuur; met de invoering van de boeken 3,5 en 6 zall waarschijnlijk nog een periode gemoeid zujn van één studentengeneratie, de invoering van boek 7 , waarin bijzondere contracten als huur worden geregeld, duurt mogelijk langer dan met opkomst, bloei en VUT van een gehele Kroondocentengeneratie is gemoeid. Toch besteed ik enige aandacht aan het NBW, in de eerste plaats omdat een deel van de hier besproken problematiek te maken heeft met de binnen redelijk afzienbare termijn in te voeren boeken 3,5 en 6 en voorts omdat het terzake bepaalde in ontwerp-bock 7, mocht het ooit tot invoering komen, nog wel enige aanpassing kan gebruiken. Ook hier bespreek ik weer - achtereenvolgens - de natrekking, het wegbreekrecht en de mogelijkheid van een vergoeding aan de huurder voor angebrachte verbeteringen.

\section{A. NATREKKING}

Algemene regel in het NBW is dat natrekking plaats vind (artt. 3.1.1.3 en 5.2.10. NBW):

a. indien een zaak zodanig met een hoodzak is verbonden, dat zij daarvan niet kan worden afgescheiden zonder beschadiging van betekenis aan een der zaken, of

b. de zaak volgens verkeersopvatting onderdeel van de zaak uitmaakt.

Tijdens de Kamerbehandeling zijn twijfels geuit over het nut van het vage criterium "verkeersopvatting". De Regeringscommissaris (Snijders) wist de Kamer er 
echter van te overtuigen dat juist die vaagheid cen van de grootste charmes van het artikel is; zij biedt de rechter de ruimte om voortdurend de maatschappelijke ontwikkelingen te volgen ${ }^{52}$.

Aldus werd de jurisprudentic op het stuk van natrekking integraal tot systeem van het NBW verheven, waarbij men zich bij herhaling afzette tegen de opvattingen van Van der Grinten ${ }^{53}$. Voor onroerend goed geldt evenwel een bijzondere bepaling (art. 5.3.1.) luidende:

De eigendom van de grond omvat, voorzover de wet niet anders bepaalt:

a. de bovengrond;

b. de daaronder zich bevindende aardlagen;

c. het grondwater dat door een bron, put of pomp aan de oppervlakte is gekonen;

d. het water dat zich op de grond bevindt en niet in open gemeenschap met water op eens anders erf staat;

e. gebouwen en werken die duurzaam met de grond zijn verenigd, hetzij rechtstreéks, hetzij door vereniging met andere gebouwen en werken, woor zover ze geen bestandderel xijn van eens anders onroerende zaak;

f. met de grond verenigde beplantingen.

De oorspronkelijke Toelichting van Meijers bevat de volgende passage $e^{54}$ :

'Dit artikel, bepalende wat de eigendom van de grond omvat, is niet overbodig naast de algemene bepaling, dat de eigenaar van een zaak eigenaar is van al haar bestanddelen (art. 5.1.5.)

Het is immers de vraag of alles wat het onderhavige artikel noemt, wel naar de definitie van artikel 3.1.1.3. als bestanddeel van de grond moet worden aangemerkt. Het onderhavige artikel maakt voor de wraag van de omvang van het eigendomsrecht op de grond overbodig een onderzoek waar hetgeen volgens verkeersopwatting als wezenlijk onderdeell van de grond geldt."

Met name de laatste zinsnede lijkt het criterium 'verkeersopvatting' bij natrekking door onroerende zaken opzij te zetten. Ten aanzien van 'gebouwen en wer"ken' lijkt de verkeersopvatting gestold in het bepaalde sub e van het artikel: bestanddeel of niet, schadeloos af te scheiden of niet, alles wat met de grond, direct of indirect verenigd is, behoort de eigenaar van de grond. Noch de Kamerbehandeling, noch de literatuur verschaft helderheid over de vraag of dit artikel

a. een limitieve opsomming geeft en

b. in welke gevallen de ene zaak geacht moet worden 'duurzaam' met de ander 'verenigd' te zijn.

Men ziet in de verte al de "verkeersopvatting" opdoemen die de rechtspraak ongetwijfeld weer zal gaan hanteren!

\section{B. WEGAREERRECHT/OORSPRONKELIJE STAAT}

Boek 7 van het Ontwerp NBW - dat overigens voorlopig niet in werking zal treden - bevat in de vierde litel, derde afdeling, een art. 3 (7.4.3.3.) dat als volgt luidt:

1. De huurder mag aan ther gehuurde goed slechts die veranderingen en toevoegingen aanbrengen, die bij het einde van de huur zonder noemenswatardige kosten kunnen worden ongedlaan gemaakt en verwijderd. 
2. De huurder is, onverminderd de rechten van de verhuunder terzake van overtreding van lid 1 , tot de ontruiming bevoegd veranderingen en twevoegingen ongedaan te maken, mits daarbij het gehuurde in de oorspronkelijke toestand terugbrengende.

3. De huurder is tot het ongedaan maken van geoorloofde veranderingen en toevoegingen slechts verplicht bij ontruiming en indien de verhuurder dit dan verlangt.' Nog wat explicieter dan het huidige BW hanteert het Ontwerp het uitgangspunt dat het gehuurde (ook als het een woning is) bij het einde van de overeenkomst in dezelfde staat moet verkeren als aan het begin. Dit - treurige - uitgangspunt wordt nogal apodictisch toegelicht ${ }^{55}$ :

Anders dan in artikel 30 van de Pachtwet 1958 aan de pachter, is aan de huurder niet de mogelijkheid gegeven om tegen de zin van de wederpartij verbeteringen aan te brengen. Bij pacht is verbetering een naar objectieve kenmerken te bepalen begrip, streven naar werbetering is an de agrarische exploitatie inherent en verbetering wain een pachtobject is in sterke mate van algemeen belang. Bij huur is dat anders.'

Geen sterke argumentatic, die overigens inmiddels al goeddeels is ondergraven door art. 1633 BW voor bedrijfsruimte. Maar ook wanneer men de huur van woningen op het oog heeft geldt dat verbeteringen vaak zeer wel objectief vaststelbaar zijn (denk aan het puntensysteem der HPW), dat de doorsnee bewoner met een huur anders dan van tijdelijke aard behoefte heeft aan aanpassingen en verbeteringen en, vanzelfsprekend, dat verbeteringen/verbeterde huurwoningen veelvuldig het algemeen belang dienen.

Maar logica kan het ontwerp niet worden ontzegd: uitgaande van de stelregel dat de oorspronkelijke staat moet wederkeren, gaat het Ontwerp er van uit dat tijdens de huur derhalve alleen veranderingen mogen worden aangebracht die weer ongedaan gemaakt kunnen worden. Sterker: zonder noemenswaardige kosten ongedaan gemaaki kunnen worden; dit om onnodig risico voor de verbuurder te voorkomen, aldus de Toelichting. Die moet immers maar afwachten of de vertrekkende huurder de veranderingen ongedaan maakt, en, zo niet, of de kosten van het ongedaan maken op de nalatige huurder kunnen worden verhaald.

De veranderingen als hier bedoeld - de zonder noemenswaardige kosten wegneembare - worden de bevoegdelijk aangebrachte veranderingen genoemd. Alle andere zijn onbevoegdelijk aangebrachte veranderingen.

Van onbevoegdelijk aangebrachte veranderingen kan de verhuurder te allen tijde, dus ook tijdens de huur, ongedaanmaking vorderen. Bevoegdelijk aangebrachte veranderingen behoeven pas bij de ontruiming ongedaan gemaakt te worden, en dan nog alleen als de verhuurder dat vraagt.

Wat nu de bevoegdheid van de huurder tot het wegnemen van aangebrachte veranderingen betreft, deze strekt zich uit over zowel de bevoegdelijke alls de onbevoegdelijke aangebrachte veranderingen. Voorwaarde is, dat de oorspronkelijke toestand wordt hersteld.

'Opgemerkt zij hierbij,' aldus de Toelichting, 'dat dit eo ipso altijd mogelijk is bij bevoegdelijk aangebrachte veranderingen, zijnde dit immers juist die veranderingen die - zonder noemenswaardige kosten - kunnen worden ongedaan gemakt ${ }^{36}$ " 
De algemene vergoedingsregeling is in het NBW te vinden in de artt. $3.5 .14 \mathrm{t} / \mathrm{m}$ 3.5.16. De regeling bevat, natst een ruime vergoeding voor de bezitter te goeder trouw en een zeer beperkte voor de bezitter te kwader trouw, ingeval de eigenaar of rech thebbende van de grond het gebouwde opeist, tevens de bevoegdheid voor de bezitter (te goeder of te kwader trouw), in plaats van aanspraak te maken op de vergoeding, de veranderingen of toevoegingen weg te nemen, mits hij de zaak in de oude toestand terugbrengt.

Een speciale vergoedingsregeling voor door huurders aangebrachte veranderingen/werbeteringen treft men in het Ontwerp niet aan. De Toelichting zegt er het wolgende over ${ }^{57}$ :

"Veranderingen en toevoegingen kunnen een verrijking van de verhuurder ten koste van de huurder ten gevolge hebben: veranderingen die verbeteringen zijn en niet ongedaan gemaakt kunnen worden of die door de hurder niet ongedaan gemaakt mogen worden omdat dit niet zonder beschadiging van het gehuurde goed mogelijk is. De vrag of terzake daarvan de huurder aanspraak heeft op vergoeding, moet aan de hand van artikel 6.4.3.1. worden beantwoord.'

De vraag is of deze verwijzing naar het bepaalde inzake ongerechtvaardigde verrijking de huurder veel zal baten. Uit de Toelichting blijkt immers dat hier vooral wordt gedacht aan de onbevoegdelijk aangebrachte veranderingen. Kan, in redelijkheid, van de verhuurder worden gevergd dat hij een vergoeding betaalt in verband met onbevoegdelijk door de huurder aangebrachte en dus hem opgedrongen veranderingen?

Beter ware geweest de woor de hand liggende aansluiting te zoeken bij de vergoedingsregelingen voor pachter en/of de huurder van bedrijfsruimte. Hoe deze kans werd gemist toont dit laatste citat uit de Toelichting ${ }^{58}$ :

"Voor een regeling als die van de Pach twet en van artikell 1633 betreffende de huur van bedrijfsruimte, gehandhaafd bij het voorgestelde artikel 7.4.6.15 ... welke ervan uitgaat dat de pachter en de huurder een zekere bevoegdheid tot verbetering van het gepachte hebben, is bij de huur in het algemeen geen aanleiding."

Tenslotte geldt dat hier sprake is van regelend recht; als partijen andere regelingen willen treffen ten aanzien wan veranderingen, verbeteringen en vergoedingen, dari staat hen dat vrij (binnen de grenzen van de wet, openbare orde en goede zeden, alsmede goede trouw, c.q. redelijkheid en billijkheid). Een blik in de (standaard) contracten is derhalve op zijn plaats.

\section{STANDAARDGONTRAGTEN}

In het voorgaande is, in meer algemene zin, cen blik geworpen op de juridische positie van de zelfwerkzane huurder: wat mag hij aan zijn woning doen, hoe moet de woning aan het einde van de overeenkomst worden opgeleverd, en welke kans makt de huurder op vergoeding van door hem aangebrachte (objectieve) verbeteringen. Op een aantal punten wees ik op - mijns Inziens - foutieve toepassing van diverse BW-bepalingen $(1598,1599,1603 \mathrm{BW})$ en stelde vast dat die 
toepassing in het NBW tot systeem dreigt te worden verheven. Op deze plaats is het juist er nog eens op te wijzen dat we hier te maken hebben met bepalingen van regelend recht, waarvan bij contract kan worden afgeweken. Of, en in welke mate dat gebeurt kan moeilijk van geval tot geval worden nagegaan. Dat hoeft gelukkig ook niet; een overgrote meerderheid van de huurwoningen in ons land word verhuurd op basis van standaardvoorwaarden. Voor de sociale sector aijn dat de standaardvoorwaarden van de Nationale Woningraad (NWR) en het Nederlands Christelijk Instituut voor de Volkshuisvesting (NCIV), waarbij vrijwel alle sociale verhuurders (inclusief tal van gemeentelijke woningbedrijven) zijn aangesloten. Samen beheren de leden van deze organisaties $66 \%$ van de Nederlandse huurwoningvoorraad. In de commerciele particuliere huursector overheerst sterk de grote particuliere verhuurder, de institutionele belegger, die het beheer overlaat aan professionele beheerders, veelal makelaars. Onder erkenning van de mogelijkheid dat individuele corporaties, gemeentelijke woningbedrijven en particuliere verhuurders eigen voorwaarden hebben opgesteld, is het niet gewaagd te veronderstellen dat een grote meerderheid van de Nederlandse huurwoningen wordt beheerd op voet van de standaard voorwaarden zoals opgesteld door, respectievelijk, de NWR, het NCIV en de ROZ (de Raad voor Onroerende Zaken, de overkoepelende organisatie voor commerciële bouwers en beheerders). Alle hiergenoemde modellen kennen een vorm van registratie van de situatie waarin het gehuurde aan het begin van de overeenkornst verkeert. Waarschijnlijk zijn deze opnamestaat (NWR), staat van bevindingen (NCIV) en inspectierapport (ROZ) de vrucht van het overleg in de Commissie-Glastra van Loon die daarop, bij wijze van uitzondering zelfs unanicm, aandrong ${ }^{59}$. In deae staten of rapporten wordt echter uitsluitend of voornamelijk gekeken naar de staat van onderhoud: wat is er kapot en wat deugt er niet. Er wordt geen exacte beschrijving gegeven van het gehuurde als zodanig. De staat is daarom, zowel voor de verhuurder als voor de huurder een gebrekkig middel om aan te tonen dat veranderingen, verbeteringen of toevoegingen aan het gehuurde zijn aangebracht.

In hoeverre mogen veranderingen worden alangebracht? De NWR is hierin zeer duidelijk: het mag niet. De huurder kan echter toestemming vragen, die door de verhuurder slechts op een aantal gronden mag worden geweigerd. Ook het ROZ kent de toestemmingsmogelijkheid met beperkte weigeringsgrond, maar laat ruimte voor zonder toestemming aangebrachte veranderingen. Beide partijen laten zich echter niet uit over de vraag of met toestemming aangebrachte veranderingen aan het einde van de overeenkomst mogen blijven zitten. In ieder geval moet in NWR-verband alles wat zonder toestemming is aangebracht worden verwijderd, terwijl in ROZ-verband aampassingen aan persoonlijke inzichten die geen verbeteringen zijn weg moeten. Van een vergoedingsregeling wordt niet gerept.

Het NGIV-model steekt hierbij nogal af. Alleen voor duurdere, ingrijpender veranderingen is toestemming vereist die verhuurder onder met name genoemde omstandigheden verplicht is te verlenen. Met toestemming aangebrachte veranderingen mogen - normaliter - altijd blijven zitten, zonder toestemming aangebrachte soms. Ook is er een overnamemogelijkheid voor de opvolgende huurder. 
Een geldelijke vergoeding voor achtergelaten verbeteringen wordt uitgesloten, tenzij in de volgende overeenkomst een hogere huurprijs kan worden bedongen.

Uitgangspunt van alle modellen is dat de huurder in principe niets mag veranderen, verbeteren of toevoegen. En dat hij, als hij daartoe overgat, de veranderingen ongedaan moet maken, en in ieder geval niet op enigerlei vergoeding behoeft te rekenen. Het maken van uitzonderingen op deze regel is een beslissing die de verhurder toekomt, waarbij vaak geen, soms vage, en bij het NCIV60 redelijke geobjectiveerde criteria worden gegeven.

\section{SLOTOPMERKINGEN}

Wie, aan het eind wan mijn betoog, cen warm pleidooi verwacht voor het slechten wan alle barrières die huurderszelfwerkzaamheid in de weg staan, komt bedrogen uit. Ook hier trekt de redelijkheid haar grenzen. Wel is er aanleiding voor een positiever benadering van huurderszelfwerkzaamheid dan die werd aangetroffen bij de wetgever ('bij huur van woonruimte is daaraan geen behoefte') en de opstellers van standaardcontracten ('alles is verboden, behalve wat mag en dat wordt niet vergoed'). Voor een dergelijke positiever benadering zal allereerst moeten worden afgerekend met de gedachte dat de huurder de woning aan het eind van de overeenkomst in de oorspronkelijke staat moet opleveren. Waar die gedachte vorm heeft gekregen in contractsclausules die iedere voorziening, door de huurder aan te brengen, op voorhand verbieden en/of rücksichtlos verwijdering van dergelijke voorzieningen bij het einde van de huurovereenkomst stipuleren, is er aanleiding dergelijke clausules als onredelijk bezwarend terzijde te schuiven. Wel is redelijk van de huurder te eisen, dat hij het gehuurde in goede staat van onderhoud oplevert. Dat is eén.

Vervolgens is de vraag aan de orde welke voorzieningen door de huurder mogen worden aangebracht. Daarbij ware, in aansluiting op het model-huurcontract van het NCIV, een onderscheid te maken in voorzieningen die zonder toestemming varn de verhuurder mogen worden aangebracht en voorzieningen waarvoor een dergelijke toestemming is vereist. Bij voorzieningen die zonder toestemming door de huurder mogen worden aangebracht moet niet het criterium zijn, dat deze zonder noemenswaardige kosten kunnen worden verwijderd, zoals art. 7.4.3.3. van het Ontwerp NBW wil - de oorspronkelijke staat heb ik immers zojuist afgezworen -; veeleer zou hebben té gelden dat het hier voorzieningen betreft die geen wezenlijke invloed hebben op het object van de hurovereenkomst. Men denke hier aan door de huurder gegranolde wanden. Voorzieningen derhalve die geen verslechtering, geen verbetering en geen uitbreiding van de woning inhouden, maar niets anders zijn dan een blote aanpassing aan de eigen smak. Deze voorzieningen doen niets toe of af aan de waarde van de woninghet puntensysteem van het Besluit huurprijzen woonruimte kan hier als meetlat fungeren - en kunnen dus ook nooit grond zijn woor vergoeding aan - of door - de huurder of diens opvolger, men zou ze 'neutraal' kunnen noemen. Dan zijn er de voorzieningen waarvoor wél toestemming is vereist; voorzieningen die wezenlijke veranderingen teweegbrengen in of aan het gehuurde. Is die verandering een 
verslechtering - ook hier kan het puntensysteem weer als meetlat fungeren - dan ligt het niet voor de hand dat een eventueel gevraagde toestemming zal worden verleend. Ik concentreer me derhalve op veranderingen die verbeteringen zijn, zoals verhoging van het uitrustingsniveau en eventued zelfs uitbreiding van de woning (dakkapel).

Ook hier dient het uitgangspunt positief te zijn, al is een sterk genuanceerde benadering op zijn plaats. Allereerst zou ik cen onderscheid willen maken tussen 'gewone' verbeteringen en andere - dus 'ongewone' - verbeteringen. Onder gewone verbeteringen versta ik dan die verbeteringen die leiden tot aanpassing van de (oude) woning aan het uitrustingsniveau van de modale nieuwbouwwoning. Men denke bijvoorbeeld aan het aanbrengen van dubbele beglazing, aan-en afvoer wasmachine, c.v.-installatie, moderne gas- en elektriciteitsleidingen, een tweede toilet, e.d. Voor het aanbrengen van deze voorzieningen zou, in principe, toestemming moeten worden verleend; in bijzondere omstandigheden kan toestemming worden geweigerd. Onder ongewone verbeteringen dienen, dat volgt uit het voorgaande, die voorzieningen te worden verstan die niet tot het uitrustingsniveau van de modale nieuwbouwwoning behoren, alsmede uitbreiding van de bestaande woning. Men denke a an het aanbrengen van een sprinkler-installatie, elektronische inbraakbeveiliging of, waar het uitbreiding betreft: de bouw van een schuur of de uitbouw van een keuken. Voor deze veranderingen kan toestemming worden verleend; onder omstandigheden zal zij moeten worden geweigerd.

Welke zijn nu die omstandigheden waaronder toestemming kan, - c.q. moetworden geweigerd?

Onder omstandigheden waarin toestemming kan worden geweigerd - woor gewone voorzieningen - dienen situaties te worden verstaan waarin van de verhuurder in redelijkheid niet kan worden gevergd dat hij toestemming voor de verandering verleent, omdat de verandering conflicteert met de eisen die de commerciële of sociale sector aan beheer en exploitatie mag stellen. De verhuurder zal daarbij niet kunnen volstaan met een vage verwijzing naar de verhuurbaarheid van de woning, maar zal aannemelijk moeten maken dat, uit een oogpunt van commercieel of sociaal beheer en exploitatie, de voorgenomen verandering ongewenst is. De eigen doelstellingen en plannen (b.v. tot collectieve renovatie) spelen daarbij een rol, maar ook de vraag- en aambodverhoudingen op de woningmarkt.

Bij omstandigheden die - in geval van ongewone veranderingen - moeten leiden tot weigering van de verandering moet vooral gedacht worden aan de sociale verhuurder. Er zijn omstandigheden waarbij een woningcorporatie, gelet op haar sociale taak, niet over mag gaan tot toestemming, namelijk in die gevallen waarin de geldelijke gevolgen van de aangebrachte verandering in conflict komen met de sociale/volkshuisvestingsdoelstelling. Dat is met name het geval als de bedoelde geldelijke gevolgen, hetzij als overnamekosten, hetzij als huurverhoging, bij wisseling van huurders prohibitief gaan werken voor de bewonerscategorie wier belangen een woningcorporatie of een gemeentelijk woningbedrijf met. name heeft te behartigen.

Dan is de vraag aan de orde wat het juridische en economische gevolg is van de 
door de huurder aangebrachte veranderingen, met name gelet op de natrekkingsregel en gericht op een passende vergoeding aan de zelfwerkzame huurder. Doorgaans wordt deze vraag pas acuut bij beeindiging van de overeenkomst. De huurder wenst een vergoeding, hetzij van de verhuurder, hetzij van zijn opvolger. Ook hier kan het onderscheid tussen 'gewone' en 'ongewone' verbeteringen een rol spelen. Bij gewone verbeteringen - die dus tot het uitrustingsniveau van de modale nieu wbouwwoningen behoren - kan worden aangenomen dat de natrekkingsregel onverkort van toepassing is; de verkeersopvatting brengt dit mee. Uitgangspunt dient te zijn, dat de huurder, behoudens andersluidend beding de hierbedoelde verbeteringen achterlaat. Daarnaast moet het uitgangspunt zijn, dat de vertrekkende huurder voor de aangebrachte verbeteringen van de verhuurder eer vergoeding on twangt die gebaseerd is op de gedane investeringen, de ouderdom van de voorzieningen en de mogelijkheid tot het bedingen van een hogere huur bij de opvolgende huurder.

Indien 'ongewone' voorzieningen met toestemming van de verhuurder zijn aangebracht, zal de huurder deze, ongeacht andershidend beding, kunnen wegbreken, mits hij de woning maar in goede staat achterlaat.

Met een beroep op de verkeersopvatting of met het 'eigen redelijk rechterlijk oordeel ${ }^{61}$ als uitgangspunt, dient hier de werking van de natrekkingsregel te worden beperkt. Aldus vormen de hierbedoelde voorzieningen een zelfstandig economisch goed waarover de huurder kan beschikken. Dat kan hij doen door de verbetering in eigendom over te dragen aan de opvolgende huurder, aan de verhuurder (middels eigendomsoverdracht of afstand van recht) of aan een derde.

Tenslotte nog dit. Ik ontveins mij niet dat, welke structuur men ook bedenkt, het aantal huurders dat zonder tocstemming min of meer ingrijpende (wezenlijke) veranderingen aan de woning aanbrengt niet gering zal zijn. Ook hier kan echter het onderscheid tussen verslechtering en verbetering, tussen gewone en ongewone verbetering, een belangrijke rol spelen bij het beantwoorden van de vraag of de voorzieningen moeten worden verwijderd, of ze worden nagetrokken en of ze moeten worden vergoed. Indien verhuurders zich echter wat flexibeler opstellen tegenover de wens van bewoners hun woning aan eigen smak en behoeften aan te passen en open staan voor een redelijke vergoeding, ligt het in de rede te veronderstellen dat de huturders steeds meer de veiliger weg van de contractuele toestemming zullen willen bewandelen.

\section{Dames en heren leden van de juridische faculteit van de Rijksaniversiteit Limburg,}

Vanaf het moment dat de eerste stukken verschenen die de basisfilosofie van de nieuwe juridische faculteit van de Rijksuniversiteit Limburg bevatten, heb ik de ontwikkelingen met meer dan gewone belangstelling gevolgd. Probleemgestuurd en grensoverschrijdend, dat leek me wel wat. Korte tijd nadat ik, met enthousiasme, aan mijn taak hier begonnen was kreeg ik de indruk dat de faculteit vooral gestuurd werd door het probleem van de onderwijsbelasting die bepaald grensoverschrijdend aan het worden was. En plots doken 'in den lande', maar ook aan 
onze eigen faculteit geruchten op dat de basisflosofie een zachte maar snelle dood aan het sterven was.

Dat is natuurlijk niet zo.

De implementatie van onze basisfilosofie is niet uitsluitend, en welfs niet voornamelijk afhankelijk van een in- of extensivering van onze onderwijsbelasting, maar veeleer van een bepaalde wetenschappelijke attitude. Niet voor niets heb ik hedenmiddag mijn rede niet gewijd aan een min of meer abstractatheoretisch privaatrechtelijk lecrstuk, maar aan een actueel maatschappelijk probleem met bovendien grensoverschrijdende kenmerken. Met $U$ hoop ik in de toekomst, in het onderwijs en in onderzoeksprojecten nog veel van dergelijke problemen te mogen aanvatten.

Dames en heren leden van de Afdeling der Bourwhinde van de Technische Hogeschool Detlf,

Tot hier hebben jullie me gebracht. Vanuit de diaspora keer ik nu terug naar een juridisch milieu. Gelukkig is de overgang geleidelijk gegaan, zowel wat de inzet in tienden werktijd, als waar het betreft de velden van wetenschapsbeaefening waarop ik de laatste tijd met $U$ actief mocht zijn, waar die geleidelijk weer juridischer en meer in het bijzonder privaatrechtelijk van aard begonnen te worden. De geleidelijkheid van de overgang wordt gemarkeerd door deze rede, die een onderwerp behandelt waarvoor ik ook in het vrije beleidsruimte onderzoeksteam $\mathrm{DHZ}$ verantwoordelijk ben.

In het bijzonder ben ik dank verschuldigd aan mijn collega en vroegere chef prof.mr. J. Wessel voor de ruimhartig geboden gelegenheid tot wetenschappelijke ontplooiing, en aan mijn collega prof.dr.ir. H. Priemus voor de inspirerende wijze waarop hij me in menig onderzoeksavontuur heeft meegesleept.

\section{Dames en heren studenten wan de faculteit der rechlsgeleerdheid,}

Nu we aan het begin van dit nieuwe collegejaar voor het eerst vier jaargroepen hebben is een belangrijke mijlpaal in de geschiedenis van onze faculteit bereikt. $U$ heeft in de afgelopen periode een pioniersfunctie vervuld. Nieuwe onderwijsmethoden zijn op $U$ losgelaten, met afwijkende en bijgestelde toetsingssystemen werd $U$ geconfronteerd, en jaarsysteem is Uw deel geworden, en steds weer was $\checkmark$ de eerste of een van de eersten op wie onderwijsblokken werden uitgeprobeerd. Als straks $U W$ afstuderen en feit 1 , is het met pionieren naturijk nog niet gedaan: U vormt die eerste belang yje groep die zijn weg in de maatschappij zal moeten zien te vinden, daarmee het pad effenend woor komende generaties afstuderenden van deze faculteit. Gelet op de situatie op de arbeidsmarkt zult $U$ dus beter of tenminste anders moeten zijn. De, zeker vergelijkenderwijs, intensieve begeleiding die $U$ geniet, te zamen met de probleengerichte grensoversehriydende benadering van ons onderwijs, zullen $U$, als $U$ de vruchteri weet te plukken, zeker behulpzaam zijn. Daarbij zijn twee zaken, hoezee begrijpelijk, ernstig te ontraden. Tijdens de studie is dat het uitshitend resultaatsgericht studeren; en na de studie is dat de eis dat de geambiecte werkplek in Limburg moet liggen. 

1. In Nederland hanteert men de wuistregel dat een huishouden gemiddeld tien jarar lang op hetzelide adres woont, aldus Priemus in Verhuistheorieen en werdeling van de woningwooratad, Delftse Universitaine Pers 1984, blz. 4.

2. Uit het recentelijk werschenen Nationaal Rayon Onderzoek, in opdracht varn het Ministerie van VROM uitgevoerd door het instituut FOSS te Oegstgeest, blijkt dat het atantal ver huizingen in de hursector ongeveer drie maal zo hoog is dan in de koopsector. Daaruit te conduderen dat huurders dus drie maal zo valk verhuizen dan eigen woning bezitters ware voorbatig ch onverantwoord, gelet $0 . \mathrm{m}$. op het hoge percentage huurwoningen in ons land en op het grote atantal 'starters' dat vooral in de huursector terecht komt..

3. Knulst en Schoenderwoerd, Waar blijft de tijd; ondereoek naar de tijdsbesteding wan Nederlanders, Socialle en Culturele Studies, 4, Sociaal Cultureel Planbureau, Rijswijk ZH, 1983.

4. Men zie TH-Beleidsruimteonderzoek 'Zelfwerkzam theid in de woningbouw', m.n. hoofdstuk 10 "Profiel wan de doe-het-zelver en zijn/haar werkzaamheden", Delftse Universitaise Pers, 1984, blz. 85 e.v.

5. Zie Smalbraak, lets over het albrekingsrecht van den Huurder, NJB 1936, bls. 312-316 en De Groot, Inleidingen to de Hollandsche rechtsgeleerdheid $11,46,8 \mathrm{t} / \mathrm{m} 12$ (Huisbourecht).

6. Ibid, III 19, 12.

7. Zie daaromtrent Beekhuis, RM Themis, blz. 466 e.w. en art. 553 CC watrin een vermoeden wan natrelkking, tot op tegenbewijs, is geformulecrd.

8. Ieder kan afzien wan de rechten die woor hem zijn geintroduceerd.

9. $\mathbb{R}$ b. Amersfoort 19 maart 1854, W 1854, nr. 1550; in par. 5 kom ik nader op deze uitspraak terug.

10. HR 16 mei 1834, W 1884, nr. 5036, angehaald bij Asser/Beekhuis, Zaketrecht II, ble. 60.

11. HR 4 december 1903, W 1904, nur. 8004 (Arena-arrest).

12. Rb. 's-Hertogenbosch, 24 december $1937, \mathrm{NJ} \| 1938$, 461.

13. Rb. Haarlem, 27 januari $1948, \mathrm{NJ} 1948,567$.

14. Hor Armhem, 30 december 1952, NJ 1953, 291.

15. Stafmateriaal-arrest, HR 11 december 1953 , NJ 1954, 115.

16. Zie b.w. Hof 's-Hertogenbosch, 3 jumi 1981, NJ 1982,73 (keukeninstallatie) en Hor's-Hertogenbosch, 18 januari 1983 , NJ 1984, 13 (bowlingbanem).

17. WPNR 1912, 2244 en in zijn bewerkingen van Assers Zakenrecht.

18. NJ 1954, bit. $231-234$ 
19. Van Opstall-bunde 1972 , blz. 12

20. Surling, Zakermechi 1940, nr. 235.

21. Asser/Deekhuis, Algemeen Ded 1957, blz, 37

22. WINR 197!, 5153.

23. WPNR 1974, 5270,

24. HR 18 mei 1951, NJ 1951, 548; HR 3 matrt 1955, NJ 1959, 496; en HR 14 januari 1959 , NJ 1959,154 .

25. Noot onder $\mathrm{HIR} 3$ maart 1954, NJ 1954,247

26. N1 1933, blz. 928 .

27. Men zie hiserover Rutten in zijn moot onder $\mathrm{NJ} 1956,27$.

28. Zir ook HR 19 oktober 1995, NJ $1956,27$.

29. Rb. Haarlem, 27 jarruari 1948, NJ 1948, 567; HR 18 mei 1951, NJ 1951, 548; Rb. Assen 18 september 1952, NJ 1952, 394; HR 3 maart 1954, NJ 1954, 247; Rb. Assen 29 maart 1955, NJ 1955,$496 ;$ HR 20 december 1957, NJ 1958, 51 en HR 14 januari 1959, NJ 1959, 154.

30. Hof Arnhem, 5 december 1956, NJ 1958, 395; Hof "swertogenbosch, 11 maart 1958, NJ 1958, 611 ; HR 18 januari 1978, NJ 1979, 565, m.n. WMK.

31. 17 juni 1984, 302.

32. Zie de uitspraken van het Hof "s-Hertogenboschi, angehaald in paragraaf 2.

33. HR 30 anpril 1948,253 (Smito Amsterdamse Huizenhandel).

34, Rb. Rottendam, 28 april 1924 , W $1924,11219$.

35. Zie ook Rb. Dordrecht, 10 december 1941, NJ 1942, 143.

36. HR 30 januari 1959, NJ 1959,458 .

37. WPNR 1954, 4341.

38. Zie hierwoor par. 2 (noot 9 ).

39.28 april 1924, W $1924,11219$.

40. Zive, heel duidelijk, Rb. Utrecht 5 juli 1939, NJ 1940, 1085; Rb. Dordrecht 10 december $1941, N J 1942,143$ en MR 30 april 1948, NJ 1949, 253.

41. Pitto, Verbintenissenrecht, 8e druk 1979, Degl 3a, blz. 108.

42. Zie noot 9 hierwoor.

43. Aanzetten voor deze opvatting vind men ook bij Petit. WPNR t.a.p. en NU 1950, 596, voorlatate en latste overweging. 


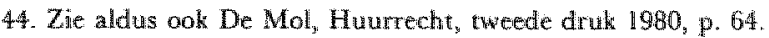

45. Ktr. Gouda, 10 februari 1977, Praktikgids 1977, ble. 369.

46. Well heeft de Cie. Glastrat wan Loon een wettelijke bepaling geadviseerd die tot oplevering door huurder in een stat van redelijkerwigze bewoonbatheid of verhwurbartheid zou dwingen. Maar dit rapport (Staatsuitgeverij 198I) heeft zoals bekend weinig parlementain wervolg gekend.

47. Ktr. Amsterdam 30 oktober 1974, Praktijkgids 1975, bl2. 106.

48. Rb. 's-Hertogenbosch 29 januari. 1982, NJ 1983, 141.

49. Dit gaat natunurlijk alleen op bij verhuurders die zich geen aanhangers tonen van de absolute oorspronkelijke staat-gedachte.

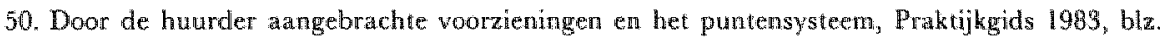
$111-115$.

51. Ktr. Amsterdam 23 november 1983, Praktijkgids 1984, bly. 427.

52. Parlementaire geschiedenis van hei Nieuw Burgerlijk Wetboek, Boek 3, Kluwer Deventer 1981 , blz. 77.

53. Ibid. blz. 77 e.v.

54. Parlementaire geschiedenis van he Nieuw Burgerljik Wetboek, Boek 5, Kluwer Deventer 1981, blz. 120 .

55. Ontwerp voor cen Nieuw Burgerlijk Wetboek, Boek 7, Toeliclating, Staatsuitgeverij 's Graventhage, 1972 , blz. 927.

56. Ibid. ble. 928 .

57. Ibid. blz. 928 .

58. Ibid. blz. 928

59. Verslag van werkzaamheden, Staatsuingeverij 1981, blz. 1394142.

60. Opmerkelijk is echter dat het NCIV model lang miet bij alle NCIV-instellingen wordt gew bruikt. Uit de ecrder vermelde enquête bleek dat nogal wat NCIV-korporaties de NWR-woorwarden gebruiken of een klassiek model hanterden.

61. Zive noot 22. 